\title{
Men and women do not have the same relation between body composition and postural sway
}

\author{
ALONSO, A. C. ${ }^{1,2 *}$, MOCHIZUKI, L. ${ }^{1}$, LUNA, N. M. S. ${ }^{1,2}$, \\ CANONICA, A. C. ${ }^{1}$, SOUZA, R. R. ${ }^{1,3}$, MAIFRINO, L. B. M. ${ }^{1,3}$, \\ FIGUEIRA JUNIOR, A. ${ }^{3}$, BOCALINI, D. S. ${ }^{2,3}$ and GREVE, J. M. D. ${ }^{1}$
}

\author{
${ }^{1}$ Movement Study Laboratory - LEM, Institute of Orthopedics and Traumatology - IOT, Faculty of \\ Medicine - FM, Clinical Hospital - HC, Universidade de São Paulo - USP, Rua Ovídeo Pires de Campos, 333, \\ Cerqueira Cesar, CEP 05403-010, São Paulo, SP, Brazil \\ ${ }^{2}$ Department of Post-Graduation in Aging Sciences, Universidade São Judas Tadeu, R. Taquari, 546, Mooca, \\ $2^{\circ}$ andar, bloco C, Secretaria da Pós Graduação, CEP 03166-000, São Paulo, SP, Brazil \\ ${ }^{3}$ Department of Post-Graduation in Physical Education, Universidade São Judas Tadeu, R. Taquari, 546, Mooca, \\ $2^{\circ}$ andar, bloco C, Secretaria da Pós-Graduação, CEP 03166-000, São Paulo, SP, Brazil \\ *E-mail: angelicacastilho@msn.com
}

\begin{abstract}
Introduction: The aim of the present study was to evaluate the influence of body composition on the postural sway during quiet standing. Our hypothesis is that men and women do not have the same relation between body composition and postural sway during quiet standing. Materials and Methods: Participated in the study 50 men and 50 women; age range: $20-40$ years old. The main outcome measures were: Body composition (bone densitometry), percentage of fat (\% fat) tissue $(\mathrm{g})$, fat $(\mathrm{g})$, lean mass $(\mathrm{g})$, bone mineral content $(\mathrm{g})$ and bone mineral density $\left(\mathrm{g} / \mathrm{cm}^{2}\right)$; Anthropometry: body mass $(\mathrm{kg})$, height $(\mathrm{cm})$, length of the trunk-head $(\mathrm{cm})$, length of lower limbs $(\mathrm{cm})$. The following indices were calculated: body mass index $(\mathrm{BMI})\left(\mathrm{kg} / \mathrm{m}^{2}\right)$ and Postural balance test-center of pressure displacement. Results: The correlation analysis showed low correlations between postural sway and anthropometric variables. The multiple linear regression model showed that the body composition and the anthropometry were able to explain only men's postural sway. Conclusion: The postural sway is sex type dependent. Men and women have different relations between body composition and postural sway. Only male's body composition affected the body sway.
\end{abstract}

Keywords: postural sway, anthropometry, young adult.

\section{Introduction}

During the quiet upright posture, there are small displacements of the body center of mass known as body sway. The control of body sway is important to avoid the lost of balance during the upright positions. The postural control changes the position of the center of pressure (COP) under the foot to control the body sway. The displacement of the COP under that situation is the postural sway. As a mechanical system, for the standing posture, the inertial properties of the body and the external and internal forces affect the control of body sway. Nevertheless, the body height and mass are two anthropometric variables that affect the body sway (LAUGHTON, SLAVIN, KATDARE et al., 2003; ALONSO, LUNA, MOCHIZUKI et al., 2012; ALONSO, MOCHIZUKI, LUNA et al., 2015).

Modeling the upright posture in the sagital plane as a single inverted pendulum, the body height and the moment of inertia are indeed two important variables for the postural control. However, the upright posture as an inverted pendulum is a very simplistic way to understand the balance control. Which advances could be added to such a model? The spring controlled inverted pendulum (GAGE, WINTER, FRANK et al., 2004; ALONSO, LUNA, MOCHIZUKI et al., 2012; ALONSO, MOCHIZUKI, LUNA et al., 2015) and the joint stiffness regulations are examples of how the inverted pendulum model was improved. The distribution of body mass affects the moment of inertia and consequently the movement of the pendulum. However, the difference in mass distribution in the body is not considered in none of the inverted pendulum models. Could the body composition (distribution of different biological tissues in the body) affect the body sway like the body mass or the body mass index? Individuals with normal or high body mass index (BMI) standing quiet on stable surfaces show similar postural sway (CHIARI, ROCCHI and CAPPELLO, 2002; BANKOFF, BEKEDORF, SCHMIDT et al., 2006; MOLIKOVA, BEZDICKOVA, LANGOVA et al., 2006), but a person with extreme BMI shows larger balance sway (GOULDING, JONES, TAYLOR, et al., 2003).

The aim of the present study was to evaluate the influence of body composition on the postural balance during quiet standing between man and woman.

\section{Materials and Methods}

\subsection{Participants}

The participants were fifty not-sedentary men and fifty not-sedentary women aged between 20-40 years old. All participants gave their written informed consent to join into 
this study, which was approved by the local ethical committee (n. 1256/06). The characteristics of those individuals are described in Table 1 . The inclusion criteria were: no history of injury to or surgery on the lower limbs and trunk; irregularly active over the last six months, as defined by the International Physical Activity Questionnaire; absence of disease or functional impairment of the auditory, vestibular, proprioceptive systems; and no current use of medications that might alter postural balance. The exclusion criteria were: inability to carry out the postural balance tests.

\subsection{Protocol}

Before the postural evaluation, the anthropometric and body composition variables were measured. The anthropometric measurements were made in accordance to the ISAK standard (LOHMAN, ROCHE and MARTORELL, 1988). The anthropometric measurements are: body mass, body height, trunk-encephalic length, lower limb length and basis of support. The body mass index (BMI) was calculated. The basis of support was measured when the individual was in the upright position, with the feet side by side and apart in a comfortable distance, without exceeding the width of the shoulders. The dual energy X-ray absorptiometry (LUNAR-DPX, Madison, Corporation, USA) was applied for the body composition (fat mass, lean mass, soft tissue mass, bone mineral composition and bone mineral density).

To calculate the area of the basis of support (BOS), the Equation 1 described by Chiari, Rocchi and Cappello (2002) was applied:

$$
B O S=\frac{\Delta \text { hallux }+\Delta \text { malleolus }}{2} \cdot L_{\text {foot }}
$$

Where $\Delta$ hallux is the distance between the hallux of each foot, $\Delta$ malleolus is the distance between the medial malleoulus of each foot and Lfoot is the length of foot in the sagital plane.
A force platform (AccuSway Plus, AMTI $^{\circledR}$, MA, USA) was applied to measure the ground reaction forces and moments of force during the quiet standing posture task. The sampling frequency of the forces $(\mathrm{F})$ and moments of forces $(\mathrm{M})$ was $100 \mathrm{~Hz}$. The center of pressure was calculated according to the following Equation 2:

$$
\begin{aligned}
& C O P_{A P}=\frac{M_{A P}}{F_{v}} \\
& C O P_{M L}=\frac{M_{M L}}{F_{v}}
\end{aligned}
$$

Where the indexes of COP, $\mathrm{M}$ and $\mathrm{F}$ indicate the direction antero-posterior (AP), medio-lateral (ML) and vertical (v). The raw signal of the COP was filtered with a $10 \mathrm{~Hz}$ low-pass $4^{\text {th }}$ order Butterworth filter. The task was to stand on the force platform in a quiet upright position with their arms alongside the body and their eyes closed. Opened eyes condition was also collected to prepare the subjects for the trials. Only eyes closed condition was analyzed to eliminate the effect of vision on postural control. Every participant performed repeated the task three times and each trial last 60s (ALONSO, LUNA, MOCHIZUKI et al., 2012; ALONSO, MOCHIZUKI, LUNA et al., 2015).

The COP variables are the root mean square (RMS) of the COP for the AP and ML directions, and its sway area (COP area).

\subsection{Statistical analysis}

The Kolmogorov-Smirnov test was used to ascertain whether the continuous variables presented normal distribution and if they did not present normal distribution, they were log transformed. Pearson's correlation coefficient was used to correlate the dependent variables (COP variables) with the independent variables (anthropometric and body composition variables) for the male and female participants. Linear

Table 1. Average and standard deviation results of the anthropometry, body composition and postural sway of the participants. Data is divided for men and women. Postural sway variables (ML COP, AP COP and COP area) were log transformed.

\begin{tabular}{cccc}
\hline Variables & Women $n=50$ & Men $n=50$ & Between sexes comparison \\
\hline Age $($ year old) & $26.4 \pm 5.1$ & $28.0 \pm 6.1$ & $\mathrm{t}=1.4 \mathrm{p}=0.15$ \\
Height $(\mathrm{cm})$ & $161.8 \pm 6.8$ & $175.8 \pm 6.2$ & $\mathrm{t}=10.7 \mathrm{p}<0.0001$ \\
Body mass $(\mathbf{k g})$ & $61.2 \pm 10.9$ & $78.6 \pm 11.8$ & $\mathrm{t}=7.6 \mathrm{p}<0.0001$ \\
BMI $\left(\mathbf{k g} / \mathbf{m}^{2}\right)$ & $23.2 \pm 3.7$ & $25.3 \pm 3.3$ & $\mathrm{t}=2.9 \mathrm{p}=0.003$ \\
Trunk-cephalic length $(\mathrm{cm})$ & $87.6 \pm 3.3$ & $83.6 \pm 5.3$ & $\mathrm{t}=4.5 \mathrm{p}<0.0001$ \\
Lower-limb length $(\mathrm{cm})$ & $74.3 \pm 4.4$ & $83.6 \pm 5.3$ & $\mathrm{t}=9.5 \mathrm{p}<0.0001$ \\
BOS $\left(\mathrm{cm}^{2}\right)$ & $306.0 \pm 56.7$ & $338.6 \pm 58.9$ & $\mathrm{t}=2.8 \mathrm{p}=0.005$ \\
\% fat & $37.3 \pm 6.6$ & $23.1 \pm 7.7$ & $\mathrm{t}=9.9 \mathrm{p}<0.0001$ \\
Soft tissue $(\mathrm{g})$ & $58997.9 \pm 10745$ & $75465.2 \pm 11711$ & $\mathrm{t}=7.3 \mathrm{p}<0.0001$ \\
Fat $(\mathrm{g})$ & $22483.4 \pm 7515$ & $18110.9 \pm 8002.6$ & $\mathrm{t}=2.8 \mathrm{p}=0.005$ \\
Lean mass $(\mathrm{g})$ & $36514.6 \pm 4963$ & $57354.3 \pm 6271.7$ & $\mathrm{t}=18.4 \mathrm{p}<0.0001$ \\
Bone mineral composition $(\mathrm{g})$ & $2347.5 \pm 333$ & $3201.7 \pm 363.5$ & $\mathrm{t}=12.2 \mathrm{p}<0.0001$ \\
Bone mineral density $\left(\mathrm{g} / \mathrm{cm}^{2}\right)$ & $1142.0 \pm 67.9$ & $1254.0 \pm 78.8$ & $\mathrm{t}=7.6 \mathrm{p}<0.0001$ \\
Log ML COP $\left(\mathrm{cm}^{2}\right)$ & $-0.62 \pm 0.17$ & $-0.59 \pm 0.15$ & $\mathrm{t}=0.9 \mathrm{p}=0.35$ \\
Log AP COP $\left(\mathrm{cm}^{2}\right.$ & $-0.32 \pm 0.17$ & $-0.33 \pm 0.12$ & $\mathrm{t}=0.3 \mathrm{p}=0.73$ \\
Log COP area $\left(\mathrm{cm}^{2}\right)$ & $0.29 \pm 0.28$ & $0.31 \pm 0.23$ & $\mathrm{t}=0.3 \mathrm{p}=0.69$ \\
\hline
\end{tabular}

BMI is body mass index, BOS is basis of support, COP is center of pressure, AP is anterior-posterior direction, ML is medio-lateral direction. 
regression model analysis was run by selecting the variables that presented $p \leq 0.20$ in the correlation coefficient analysis. These variables were ranked from lowest to highest $p$ value. A multiple modeling process using stepwise forward selection was then conducted, the variables were added to the model one by one, according to their ranking. The variables whose $p$ value was $\leq 0.05$ were kept in the model (ALONSO, LUNA, MOCHIZUKI et al., 2012; ALONSO, MOCHIZUKI, LUNA et al., 2015). The statistical data analysis was run in the SPSS 20.0 software.

\section{Results}

\subsection{Correlation analysis}

The correlation coefficients of the anthropometric variables in relation to postural sway in men and women are described in Table 2. For men, the body height, lower limb length and BOS were correlated to ML COP; while, the body mass and $\mathrm{BMI}$ were correlated to AP COP and body height, body mass and lower limb were correlated to COP area. For women, body height and lower limb length were correlated to ML COP; while, body height was correlated to body height.

The correlation coefficients of the body composition variables in relation to postural sway in men and women are described in Table 2. For men, the lean mass was correlated to ML COP, AP COP and COP area, and the soft tissue mass was correlated to AP COP and COP area. For women, no body composition variable was correlated to postural sway.

\subsection{Regression analysis}

The results of the multivariable linear regression analysis among the anthropometric and body composition variables and postural sway are described in Table 3. For men, the body height and support base area explained $28 \%$ of the accounted variability of ML COP, the lean mass explained $10 \%$ of the accounted variability of AP COP, and BOS and lean mass explained $25 \%$ of the accounted variability of COP area. For women, no relation was found.

Table 2. The coefficient of correlation between postural sway and the anthropometric or body composition variables in men and women. BMI is body mass index.

\begin{tabular}{|c|c|c|c|c|c|c|}
\hline \multirow{3}{*}{ Variables } & \multicolumn{6}{|c|}{ Coeficient of correlation R (level of significance $\mathrm{p}$ ) } \\
\hline & \multicolumn{2}{|c|}{ Log ML COP } & \multicolumn{2}{|c|}{ Log AP COP } & \multicolumn{2}{|c|}{ COP area } \\
\hline & Women & Men & Women & Men & Women & Men \\
\hline Height (cm) & $0.44(0.001)^{*}$ & $0.40(0.004)^{*}$ & $0.09(0.52)$ & $0.15(0.27)$ & $0.29(0.04)^{*}$ & $0.35(0.01)^{*}$ \\
\hline Mass (kg) & $0.12(0.39)$ & $0.26(0.06)$ & $-0.03(0.79)$ & $0.33(0.01)^{*}$ & $0.06(0.67)$ & $0.35(0.01)^{*}$ \\
\hline $\mathrm{BMI}\left(\mathrm{kg} / \mathrm{m}^{2}\right)$ & $-0.04(0.75)$ & $0.07(0.60)$ & $-0.06(0.64)$ & $0.29(0.04)^{*}$ & $-0.04(0.74)$ & $0.19(0.17)$ \\
\hline $\begin{array}{l}\text { Trunk-cephalic length } \\
(\mathrm{cm})\end{array}$ & $0.24(0.09)$ & $0.14(0.30)$ & $0.16(0.26)$ & $-0.002(0.99)$ & $0.21(0.13)$ & $0.12(0.40)$ \\
\hline Lower-limb length $(\mathrm{cm})$ & $0.38(0.005)^{*}$ & $0.32(0.02)^{*}$ & $-0.03(0.83)$ & $0.17(0.23)$ & $0.18(0.18)$ & $0.30(0.03)^{*}$ \\
\hline $\operatorname{BOS}\left(\mathrm{cm}^{2}\right)$ & $0.003(0.98)$ & $-0.38(0.006)^{*}$ & $0.04(0.78)$ & $0.03(0.82)$ & $0.02(0.88)$ & $-0.26(0.06)$ \\
\hline$\%$ fat & $-0.12(0.40)$ & $-0.01(0.90)$ & $-0.12(0.38)$ & $0.07(0.59)$ & $-0.12(0.39)$ & $0.04(0.75)$ \\
\hline Soft tissue $(\mathrm{g})$ & $0.12(0.39)$ & $0.26(0.06)$ & $-0.02(0.86)$ & $0.33(0.01)^{*}$ & $0.06(0.63)$ & $0.35(0.01)^{*}$ \\
\hline Fat $(g)$ & $0.013(0.92)$ & $0.08(0.57)$ & $-0.06(0.63)$ & $0.22(0.12)$ & $-0.009(0.94)$ & $0.17(0.21)$ \\
\hline Lean mass $(\mathrm{g})$ & $0.24(0.08)$ & $0.39(0.005)^{*}$ & $0.05(0.72)$ & $0.34(0.01)^{*}$ & $0.16(0.25)$ & $0.42(0.002)^{*}$ \\
\hline $\begin{array}{l}\text { Bone mineral } \\
\text { composition }(\mathrm{g})\end{array}$ & $0.24(0.08)$ & $0.22(0.12)$ & $-0.03(0.81)$ & $0.12(0.40)$ & $0.12(0.40)$ & $0.21(0.14)$ \\
\hline $\begin{array}{l}\text { Bone mineral density } \\
\left(\mathrm{g} / \mathrm{cm}^{2}\right)\end{array}$ & $0.12(0.39)$ & $-0.09(0.51)$ & $-0.18(0.20)$ & $-0.06(0.65)$ & $-0.03(0.79)$ & $-0.08(0.54)$ \\
\hline \multicolumn{7}{|c|}{$\begin{array}{l}\text { BMI is body mass index, BOS is basis of support, COP is center of pressure, AP is anterior-posterior direction, ML is medio-lateral } \\
\text { direction. The statistical significant coefficients }(\mathrm{p}<0.05) \text { are marked with * and printed in bold numbers. Postural sway variables } \\
\text { (ML COP, AP COP and COP area) were log transformed. }\end{array}$} \\
\hline \multicolumn{7}{|c|}{$\begin{array}{l}\text { Table 3. The linear coefficient and the level of significance data related to the multivariate linear regression model analysis on the } \\
\text { relation of postural sway (ML COP, AP COP and COP area) and the anthropometric and body composition variables for men and } \\
\text { women. Postural sway variables (ML COP, AP COP and COP area) were log transformed. }\end{array}$} \\
\hline \multicolumn{7}{|c|}{ Beta value of the linear regression analysis (level of significance $p$ ) } \\
\hline & ables & Height & BOS & Lean & mass & $\mathbf{r}^{2}$ \\
\hline \multirow[t]{3}{*}{ Women } & COP & - & - & & - & 00.15 \\
\hline & COP & - & - & - & - & 0.05 \\
\hline & area & - & - & - & - & - \\
\hline \multirow[t]{3}{*}{ Men } & COP & $.01(<0.001)$ & $-0.001(<0.0$ & $01)$ & & 0.28 \\
\hline & $\mathrm{COP}$ & - & - & $60.7(c$ & $0.01)$ & 0.10 \\
\hline & area & - & $-0.001(0.01$ & $10.7(<$ & $<0.001)$ & 0.25 \\
\hline
\end{tabular}

BOS is basis of support, COP is center of pressure, AP is anterior-posterior direction, ML is medio-lateral direction. 


\section{Discussion}

Our main result supports the hypothesis that men and women have different relations between body composition and postural sway. Only male's body composition affected the body sway. The difference between sexes in body composition can slightly change the behavior of the inverted pendulum model. The inverted pendulum model should be carefully applied to study the postural control (ALONSO, MOCHIZUKI, LUNA et al., 2015). In order to avoid any misunderstanding during the analysis of the inverted pendulum model applied to the quiet standing posture, it is necessary to consider the mass distribution in the calculus for the position of the center of mass. For the ankle strategy, which is responsible for the most of postural sway in AP direction, neither the anthropometry nor the body composition correlates to the postural sway in women. Moreover, the importance of lean mass for the postural sway differs due to sex type. Only for men, the lean mass correlates to the postural sway.

The body height and the lower limb length affected the weight transfer strategy. The body weight bouncing between feet during standing support is the weight transfer strategy and it is related to the ML COP sway. Curiously, the trunk-cephalic length does not correlate to the postural sway. Although most of body mass is located above the hips, it seems that it is not the main factor for the ML COP sway.

The weight transfer strategy depends on different variables according to sex. For men, it is also important the size of the basis of support and their lean mass; while, for women, only the lengths (whole body and lower limbs) are important. Indeed, the lower basis of supports leads to higher postural sway in ML direction (CHIARI, ROCCHI and CAPPELLO, 2002; MOCHIZUKI, DUARTE, AMADIO et al., 2006; MANN, KLEINPAUL, TEIXEIRA et al., 2008; CHOU, CHENG, CHEN et al., 2009), and to control the increase in body sway, it is necessary to increase the lean mass, probably and mainly, the muscle mass to be able to generate more muscle force.

The greater the lean mass, the smaller was the postural sway. Although this statement can only be addressed to the male participants, the lost of muscular force is a risk factor for accidental falls. Two important facts in our results: in one hand, the increase in lean mass correlates to the decrease of the amplitude of the postural sway, on the hand, such an increase in lean mass also decreases the COP area. For the participants with large lean mass, those facts suggest that their postural sway is also safer than who have less lean mass. The safety in postural sway does not relate to its size, but also depends about how far is the COP to the border of the BOS.

The increase in body height affects the body mass and soft-tissue mass (lean and fat masses) increases the postural sway. The increase in body mass indeed enlarges the postural sway (CHIARI, ROCCHI and CAPPELLO, 2002; BANKOFF, BEKEDORF, SCHMIDT et al., 2006; MOLIKOVA, BEZDICKOVA, LANGOVA et al., 2006); but, now we can say that such an effect depends on the person's sex. Winters and Snow (2000) and Mainenti, Rodrigues, Oliveira et al. (2011) showed that DEXA and bioimpedance are important for settling controversies, given that body mass and BMI are less refined measurements.

The percentage of fat mass explains part of the AP postural sway in men, but not in women. There are few studies on body composition variables and postural sway for comparison purposes. For young women, the absence of relation between fat mass and postural sway suggests that fat mass effects on the postural control is aging dependent. Mainenti, Rodrigues, Oliveira et al. (2011) showed that elderly women with more fat mass had larger balance sway and Winters and Snow (2000) reported that $31 \%$ of postural sway variability in premenopausal women was caused by the fat mass.

The increase in body height indeed increases the postural sway (KEJONEN, KAURANEN and VANHARANTA, 2003; HUE, SIMONEAU, MARCOTTE et al., 2007; FABUNMI and GBIRI, 2008). The linear regression analysis showed that height explained about of one fourth of the variations in postural sway. Berger, Trippel, Discher et al. (1992) stated that ankle displacements and the response of the gastrocnemius increased with increasing height. Allard, Nault, Hinse et al. (2001) and Lee and Lin (2007) reported that ectomorph individuals presented greater postural sway that shown by endomorph and mesomorph individuals, and they attributed this to their higher center of mass. The greater height in the male group may have been the reason for the greater influence of this parameter on COP in comparison to the females participants.

In our study, for the young adults, without major health diseases or other abnormalities, the anthropometric variables had different relations to postural sway according to sex. We suggest that for the ankle and weight transfer strategies and COP sway, the difference between sexes should be accounted before major conclusions.

\section{Conclusions}

The postural sway is sex type dependent.

The importance of body composition in postural sway depends also on the sex type. Men's postural sway correlates to the lean mass and soft tissue mass.

\section{References}

ALLARD, P., NAULT, ML., HINSE, S., LEBLANC, R. and LABELLE, $\mathrm{H}$. Relationship between morphologic somatotypes and standing posture equilibrium. Annals of Human Biology, 2001, vol. 28, n. 6, p. 624-633. http://dx.doi.org/10.1080/03014460110047946. PMid:11726039.

ALONSO, AC., LUNA, NM., MOCHIZUKI, L., BARBIERI, F., SANTOS, $S$. and GREVE, JM. The influence of anthropometric factors on postural balance: the relationship between body composition and posturographic measurements in young adults. Clinics, 2012, vol. 67, n. 12, p. 1433-1441. http://dx.doi.org/10.6061/clinics/2012(12)14. PMid:23295598.

ALONSO, AC., MOCHIZUKI, L., LUNA, NMS., AYAMA, S., CANONICA, AC. and GREVE, JM. Relation between the sensory and anthropometric variables in the quiet standing postural control: is the inverted pendulum important for the static balance control? BioMed Research International, 2015. Article ID 985312.

BANKOFF, ADP., BEKEDORF, RG., SCHMIDT, A., CIOL, P. and ZANAI, CA. Análise do equilíbrio corporal estático através de um baropodômetro eletrônico. Revista Conexões, 2006, vol. 4, n. 2, p. 19-29.

BERGER, W., TRIPPEL, M., DISCHER, M. and DIETZ, V. Influence of subjects' height on the stabilization of posture. Acta Oto-Laryngologica, 1992, vol. 112, n. 1, p. 22-30. http://dx.doi. org/10.3109/00016489209100778. PMid:1575033.

CHIARI, L., ROCCHI, L. and CAPPELLO, A. Stabilometric parameters are affected by anthropometry and foot placement. Clinical 
Biomechanics (Bristol, Avon), 2002, vol. 17, n. 9-10, p. 666-677. http:// dx.doi.org/10.1016/S0268-0033(02)00107-9. PMid:12446163.

CHOU, SW., CHENG, HY., CHEN, JH., JU, YY., LIN, YC. and WONG, MK. The role of the great toe in balance performance. Journal of Orthopaedic Research: Official Publication of the Orthopaedic Research Society, 2009, vol. 27, n. 4, p. 549-554. http://dx.doi. org/10.1002/jor.20661. PMid:18932241.

FABUNMI, AA. and GBIRI, CA. Relationship between balance performance in the elderly and some anthropometric variables. African Journal of Medicine and Medical Sciences, 2008, vol. 37, n. 4, p. 321-326. PMid:19301708.

GAGE, WH., WINTER, DA., FRANK, JS. and ADKIN, AL. Kinematic and kinetic validity of the inverted pendulum model in quiet standing. Gait \& Posture, 2004, vol. 19, n. 2, p. 124-132. http://dx.doi. org/10.1016/S0966-6362(03)00037-7. PMid:15013500.

GOULDING, A., JONES, IE., TAYLOR, RW., PIGGOT, JM. and TAYLOR, D. Dynamic and static tests of balance and postural sway in boys: effects of previous wrist bone fractures and high adiposity. Gait \& Posture, 2003, vol. 17, p. 136-141.

HUE, O., SIMONEAU, M., MARCOTTE, J., BERRIGAN, F., DORÉ, J., MARCEAU, P., MARCEAU, S., TREMBLAY, A. and TEASDALE, N. Body weight is a strong predictor of postural stability. Gait \& Posture, 2007, vol. 26, n. 1, p. 32-38. http://dx.doi. org/10.1016/j.gaitpost.2006.07.005. PMid:16931018.

KEJONEN, P., KAURANEN, K. and VANHARANTA, H. The relationship between anthropometric factors and body-balancing movements in postural balance. Archives of Physical Medicine and Rehabilitation, 2003, vol. 84, n. 1, p. 17-22. http://dx.doi. org/10.1053/apmr.2003.50058. PMid:12589615.

LAUGHTON, CA., SLAVIN, M., KATDARE, K., NOLAN, L., BEAN, JF., KERRIGAN, DC., PHILLIPS, E., LIPSITZ, LA. and COLLINS, JJ. Aging, muscle activity, and balance control: physiologic changes associated with balance impairment. Gait \& Posture, 2003, vol. 18, n. 2, p. 101-108. http://dx.doi.org/10.1016/S09666362(02)00200-X. PMid:14654213.

LEE, AJ. and LIN, WH. The influence of gender and somatotype on single-leg upright standing postural stability in children. Journal of Applied Biomechanics, 2007, vol. 23, n. 3, p. 173-179. PMid:18089914.
LOHMAN, TG., ROCHE, AF. and MARTORELL, R. Anthropometric standartization reference manual. Champaign: Human Kinectics Books, 1988. 177 p.

MAINENTI, MR., RODRIGUES, EC., OLIVEIRA, JF., FERREIRA, AS., DIAS, CM. and SILVA, AL. Adiposity and postural balance control: correlations between bioelectrical impedance and stabilometric signals in elderly Brazilian women. Clinics, 2011, vol. 66, n. 9, p. 1513-1518. PMid:22179151.

MANN, L., KLEINPAUL, JF., TEIXEIRA, CS., LOPES, LFD. and MOTA, CB. A utilização de diferentes bases de apoio com e sem informação visual na manutenção do equilíbrio corporal de idosas. Acta ORL, 2008, vol. 26, n. 4, p. 216-221.

MOCHIZUKI, L., DUARTE, M., AMADIO, AC., ZATSIORSKY, VM. and LATASH, ML. Changes in postural sway and its fractions in conditions of postural instability. Journal of Applied Biomechanics, 2006, vol. 22, n. 1, p. 51-60. PMid:16760567.

MOLIKOVA, R., BEZDICKOVA, M., LANGOVA, K., HOLIBKA, V., DAVID, O., MICHALIKOVA, Z. and REHOROVA, J. The relationship between morphological indicators of human body and posture. Biomedical Papers of the Medical Faculty of the University Palacky, Olomouc, Czechoslovakia, 2006, vol. 150, n. 2, p. 261-265. http://dx.doi.org/10.5507/bp.2006.038. PMid:17426789.

WINTERS, KM. and SNOW, CM. Body composition predicts bone mineral density and balance in premenopausal women. Journal of Women's Health \& Gender-Based Medicine, 2000, vol. 9, n. 8, p. 865-872. http://dx.doi.org/10.1089/152460900750020892. PMid:11074952.
Received June 28, 2015

Accepted September 1, 2015 